\title{
Cardanol-based thermoset plastic reinforced by sponge gourd fibers (Luffa cylindrica)
}

\author{
André Leandro da Silva ${ }^{1 *}$, Lucas Renan Rocha da Silva1, Isabelle de Andrade Camargo², \\ Deuber Lincon da Silva Agostini ${ }^{3}$, Derval dos Santos Rosa², Diego Lomonaco Vasconcelos de Oliveira1, \\ Pierre Basílio Almeida Fechine ${ }^{4}$ and Selma Elaine Mazzetto ${ }^{1}$
}

\author{
${ }^{1}$ Department of Organic and Inorganic Chemistry, Universidade Federal do Ceará - UFC, \\ Fortaleza, CE, Brazil \\ ${ }^{2}$ Center for Engineering, Modeling and Applied Social Sciences, Universidade Federal do ABC - UFABC, \\ Santo André, SP, Brazil \\ ${ }^{3}$ Department of Physics, Chemistry and Biology, Universidade Estadual Paulista - UNESP, \\ Presidente Prudente, SP, Brazil \\ ${ }^{4}$ Department of Analytical Chemistry and Physical Chemistry, Universidade Federal do Ceará - UFC, \\ Fortaleza, CE, Brazil \\ *andre.leandro@ufcg.edu.br
}

\begin{abstract}
A growing global trend for maximum use of natural resources through new processes and products has enhanced studies and exploration of renewable natural materials. In this study, cardanol, a component of the cashew nut shell liquid (CNSL), was used as a building block for the development of a thermosetting matrix, which was reinforced by raw and modified sponge gourd fibers (Luffa cylindrica). DSC and TG results showed that among biocomposites, the one reinforced by sponge gourd fibers treated with $\mathrm{NaOH} 10 \mathrm{wt} \%$ (BF10) had the highest thermal stability, besides the best performance in the Tensile testing, showing good incorporation, dispersion, and adhesion to polymer matrix, observed by SEM. After 80 days of simulated soil experiments, it has been discovered that the presence of treated fiber allowed better biodegradability behavior to biocomposites. The biobased thermoset plastic and biocomposites showed a good potential to several applications, such as manufacturing of articles for furniture and automotive industries, especially BF10.
\end{abstract}

Keywords: biobased plastic, biodegradable, composites, lignocellulosic fibers.

\section{Introduction}

A growing global trend for maximum use of natural resources through new processes and products has enhanced researches and exploration of renewable natural materials ${ }^{[1]}$.

Cashew nut shell liquid (CNSL) is a remarkable example of a renewable resource often used in polymeric materials syntheses. It is a viscous liquid in the soft honeycomb of the cashew nut, which is the crop of the cashew tree, Anacardium occidentale L, native to Brazil ${ }^{[2]}$.

Anacardic acid, cardanol, cardol, and 2-methylcardol are phenolic compounds with long side chain substitution at the meta position and the main components of CNSL. These phenolic compounds can be used for producing a number of polymeric substances of wide utility in several industrial applications. The use of CNSL instead of phenol is an excellent example of conservation of a synthetically derived substance and the utilization of a byproduct ${ }^{[3]}$.

Commercial grade CNSL, also known as technical CNSL, hardly contains any anacardic acid, because of decarboxylation during the roasting process, which converts anacardic acid into cardanol ${ }^{[4]}$.

Cardanol is a mixture of compounds with a changeable number of unsaturations in the fifteen carbon atom chains, which is in the meta position to the hydroxyl group ${ }^{[5]}$. Cardanol-based polymers and polymeric materials are both documented in the literature ${ }^{[6]}$, as well as the focus of continuing researches. Among the CNSL constituents, cardanol is a viable option to polymeric materials synthesis, because of this compound it is a monosubstituted phenol, which decreases the problem of steric hindrance during the polymerization reaction.

There is a great interest in the use of composite materials from polymer matrices reinforced by natural fibers ${ }^{[7]}$. Environment-friendly materials, their development and cleaner production processes have been needed to preserve the environment and guarantee improved living conditions for future generations.

Lignocellulosic fibers are natural biopolymers constituted primarily of cellulose, hemicelluloses, and lignin, which contribute differently to the mechanical strength of the composite ${ }^{[8,9]}$. The application of natural fibers as a reinforcement provides composite materials with low density, higher porosity, satisfactory values of tensile strength, and impact resistance, besides greater control of fissuration and ductile behavior at break ${ }^{[10-12]}$.

Natural fibers present advantages such as low cost, excellent resistance to solvents, and to temperature. In addition, they are non-toxic, non-abrasive, and easily modified by chemicals $^{[13]}$. These characteristics make fibers feasible 
materials for many applications such as in carpets, vases, cords, roof tiles, automotive upholsteries, mattresses, etc ${ }^{[14]}$. Lignocellulosic fibers have been widely investigated and used as reinforcement in polymer matrices such as coconut fibers $^{[15]}$, jute ${ }^{[16]}$, sisal ${ }^{[17]}$, banana tree ${ }^{[18]}$.

Sponge gourd fiber (Luffa cylindrica) is an interesting raw material and it has not yet had its potentialities fully explored. It is a subtropical plant, abundant in China, Japan, and other Asian countries as well as countries in Central and South America. Sponge gourd has a netting-like fibrous vascular system, which is thin, resistant, viscoelastic, and soft, used mainly as a bath sponge ${ }^{[19]}$. The chemical composition of sponge gourd fibers depends on several factors such as plant origin, weather conditions, soil nature, etc. For instance, cellulose content varies from $55 \%$ to $90 \%$, lignin content from $10 \%$ to $23 \%$, and hemicellulose content from $8 \%$ to $22 \%{ }^{[20,21]}$.

However, lignocellulosic fibers are hydrophilic and because of it there is low compatibility with the polymer matrix, which is mostly hydrophobic ${ }^{[7]}$. This lack of affinity results in a low surface of adhesion, which affects the transference of effective tensions, compromising mechanical properties of composites ${ }^{[22,23]}$. Therefore, a pretreatment is necessary before using these fibers as a reinforcement in polymer matrices. Alkaline treatment is a known method to surface modification of fibers and can provide better adhesion.

The main motivation of this research was due to the fact that any study has not been reported in the literature on the preparation and characterization of a thermoset plastic based on cardanol and reinforced by raw and treated sponge gourd fibers so far. The termoset plastic and the biocompostes were investigated by techniques of Gas Chromatography-Mass Spectrometry (GC-MS), Differential Scanning Calorimetry (DSC), Thermogravimetry (TG), Tensile testing, Scanning Electron Microscopy (SEM) and Biodegradation in simulated soil. In addition, this paper has also included a study on the crosslinking degree and cure conditions by a low-cost gravimetric method.

\section{Materials and Methods}

\subsection{Sponge gourd fibers, technical CNSL and chemical reagents}

Sponge gourd fibers were purchased commercially (São Paulo - SP, Brazil) without any skin. Sodium hydroxide (NaOH - 97\% - Dynamic) and a commercial sodium hypochlorite solution ( $\mathrm{NaClO}-2.0 \mathrm{wt} \%$ of active chlorine) were used for alkaline treatment and bleaching of fibers. The technical CNSL used in this study was kindly provided by Amêndoas do Brasil Ltda (Fortaleza, Brazil). Methanol ( $\mathrm{CH}_{3} \mathrm{OH}$ - 99.8\% - Dynamic), ammonium hydroxide $\left(\mathrm{NH}_{4} \mathrm{OH}\right.$ - 28-30\% - Dynamic), hexane $\left(\mathrm{C}_{6} \mathrm{H}_{14}-98.5 \%\right.$ - Dynamic), anhydrous sodium sulfate $\left(\mathrm{Na}_{2} \mathrm{SO}_{4}-99 \%\right.$ - Dynamic), hydrochloric acid ( $\mathrm{HCl}-37 \%$ - Dynamic), formaldehyde ( $\mathrm{CH}_{2} \mathrm{O}$ - 36.5-38\% - Dynamic), diethylenetriamine - DETA $\left(\mathrm{C}_{4} \mathrm{H}_{13} \mathrm{~N}_{3}-99 \%\right.$ - Sigma-Aldrich $)$, toluene $\left(\mathrm{C}_{7} \mathrm{H}_{8}-99.5 \%\right.$ - Dynamic) were used without any prior treatment. Resin epoxy DGEBA(Bisphenol A diglycidyl ether) was obtained from Avipol (São Paulo, Brazil).

\subsection{Alkaline treatment}

Simple procedures were conducted prior to the sponge gourd fibers such as cutting, seeds removal, milling, and drying. Previously dried fibers were ground in a Wiley mill (FORTINOX-STAR FT 80) and fractions until 30 mesh were collected.

Sponge gourd fibers were treated with sodium hydroxide solutions $5 \mathrm{wt} \%$ and $10 \mathrm{wt} \%$ at $65^{\circ} \mathrm{C}$ for $4 \mathrm{~h}$. Fibers were washed with distilled water to remove excess of $\mathrm{NaOH}$ until neutral $\mathrm{pH}$ was achieved. Thereafter, fibers were treated with sodium hypochlorite solution $1 \mathrm{wt} \%$ of active chlorine at $65^{\circ} \mathrm{C}$ for $1 \mathrm{~h}$. Eventually they were washed with distilled water to remove excess of $\mathrm{NaClO}$ and dried in an air circulation oven at $65^{\circ} \mathrm{C}$.

\subsection{Prepolymer resol synthesis}

Prepolymer resol synthesis was carried out in a laboratory glass reactor equipped with a stirrer, thermometer and reflux condenser. Cardanol was previously isolated from technical CNSL by the method proposed by Kumar et al ${ }^{[24]}$. Resol was synthesized by mixing cardanol and formaldehyde aqueous solution, and ammonium hydroxide as a catalyst. The mixture was heated until $80^{\circ} \mathrm{C}$ for $3 \mathrm{~h} 30$ min under magnetic stirring. Cardanol/Formaldehyde with a molar ratio of 1:2 was prepared in this synthesis.

\subsection{Termoset plastic and biocomposites preparation}

The thermoset plastic (Figure 1b-d) was prepared by mixing the prepolymer resol and epoxy resin as a modifier agent, and diethylenetriamine as a catalyst in the proportion 0.93:1:0.11 (wt), respectively. The use of aliphatic amines as catalysts enables materials to be produced under normal conditions of temperature and pressure, which facilitates their processing. The mixture was transferred to a metal mold with $180 \mathrm{~mm}$ high, $160 \mathrm{~mm}$ wide and, $5 \mathrm{~mm}$ thick (Figure 1a), then cured at ambient temperature for $48 \mathrm{~h}$ in a dispensing hood and post-cured in the oven at $100^{\circ} \mathrm{C}$ for $4 \mathrm{~h}$. Carnauba wax was used as a mold release agent. The cardanol-based resin was used as a polymer matrix and biocomposites (Figure 1e-g) were prepared by using treated and untreated sponge gourd fibers as dispersed phase (Matrix/Fiber with weight ratio of $85: 15)$. The biocomposites processing conditions were the same used for the thermoset plastic.

\subsection{Crosslinking degree determination}

A gravimetric technique based on ASTM D2765 ${ }^{[25]}$ was used to crosslinking degree investigation. Samples of the thermoset plastic were weighed (Wi) and then immersed in toluene for $24 \mathrm{~h}$ to extract the soluble content and determine the crosslinking degree (CD). At the end of this period, samples were dried at ambient temperature to constant weight and again weighed (Wf). The experiments were performed in triplicate for the thermoset plastic cured at ambient temperature for $48 \mathrm{~h}$, as well as post-cured at 60 , 80 , and $100^{\circ} \mathrm{C}$ for $2 \mathrm{~h}$. After that, another experiment was conducted, in which the temperature was fixed and the CD was measured to post-cure ranges of $30,60,120,180,240$, 300 , and $360 \mathrm{~min}$. The CD was calculated by the Equation 1 


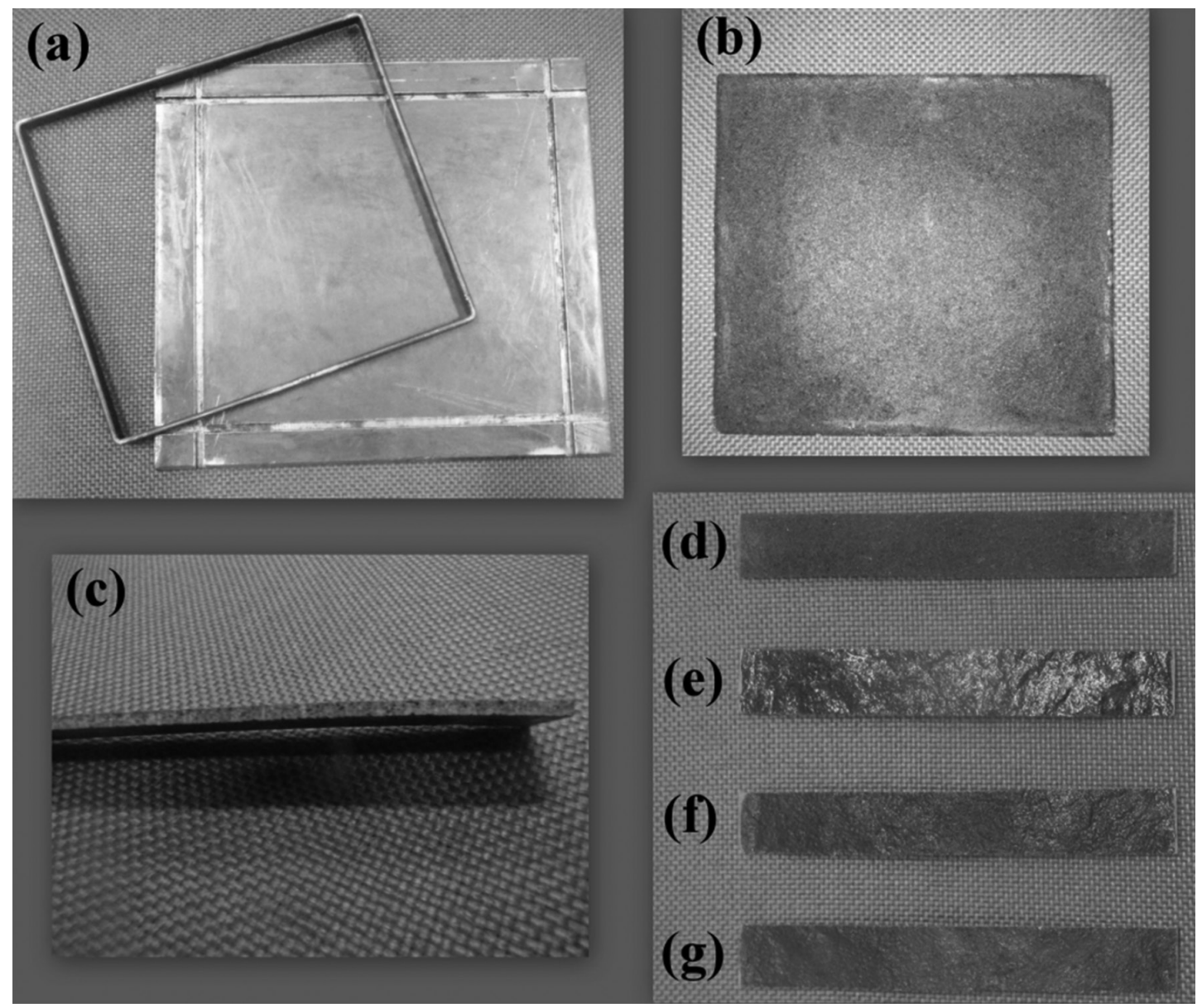

Figure 1. (a) Metal mold; (b) thermoset plastic after demolding; (c) thermoset plastic cross section; (d) thermoset plastic after cutting, and biocomposite after cutting reinforced by (e) untreated sponge gourd fiber, and fiber treated with $\mathrm{NaOH}$; (f) $5 \mathrm{wt} \%$ and (g) $10 \mathrm{wt} \%$.

below. The toluene used as solvent was chosen based on prior solubility tests with the thermoset plastic.

$$
C D(\%)=\frac{M f}{M i} \times 100
$$

\subsection{Gas chromatography-Mass spectrometry (GS-MS)}

GC-MS analysis of cardanol was conducted in a QP 2010 chromatographer (Shimadzu), equipped with a DB-5 column (phenyl methylpolysiloxane 5\%). The injected volume of each sample was about $1 \mu \mathrm{l}$ and helium was used as a carrier gas. The total pressure, total flow and the split ratio were $58 \mathrm{KPa}, 87.4 \mathrm{ml} / \mathrm{min}$, and 100 , respectively. The ion source temperature was $230{ }^{\circ} \mathrm{C}$, the interface temperature was $300^{\circ} \mathrm{C}$, and the mass ratio of detection was $18-800$.

\subsection{Thermogravimetry (TG)}

TG curves were obtained in a TG STA 6000 equipment (Perkin Elmer) under $\mathrm{N}_{2}$ atmosphere (flow rate of $50 \mathrm{ml} / \mathrm{min}$ ), heating rate of $10^{\circ} \mathrm{C} / \mathrm{min}$ in a temperature range between 30 and $600{ }^{\circ} \mathrm{C}$ to evaluate thermal stability of the thermoset plastic and biocomposites. Platinum pan was used and the weight of each sample was about $3 \mathrm{mg}$.

\subsection{Differential scanning calorimetry (DSC)}

DSC curves were obtained in a DSC Q-20 equipment (TA Instruments) under $\mathrm{N}_{2}$ atmosphere (flow rate of $50 \mathrm{ml} / \mathrm{min}$ ), heating rate of $10^{\circ} \mathrm{C} / \mathrm{min}$ in a temperature range between $30{ }^{\circ} \mathrm{C}$ and $400{ }^{\circ} \mathrm{C}$ to study cure degree and look at how heat capacity of the thermoset plastic and biocomposites is changed by temperature. Hermetic aluminum pan was used and the weight of each sample was about $2.5 \mathrm{mg}$.

\subsection{Tensile testing}

Tensile testing was performed on the thermoset plastic and biocomposites in a DL 10000/700 tensile machine (Emic) with $100 \mathrm{kN}$ of load cell. The test speed was $5 \mathrm{~mm} / \mathrm{min}$ and specimens were prepared with $175.0 \mathrm{~mm}$ high, $25 \mathrm{~mm}$ wide, and $5 \mathrm{~mm}$ thick. A minimum of five samples were tested to each material and the average value was calculated. This test was conducted according to ASTM D638 ${ }^{[26]}$ and ASTM D3039[27].

\subsection{Scanning eletron microscopy (SEM)}

The thermoset plastic and biocomposites were previously coated with a thin layer of metallic gold in a sputter coater Q150R ES (Quorum). An electron microscope SSX-550 
(Shimadzu) was used to get micrographs from fractured surface of specimens after Tensile testing at an accelerating voltage of $15 \mathrm{kV}$.

\subsection{Biodegradation in simulated soil}

The biodegradation was investigated by submitting the samples to simulated soil. They were weighed and buried at $25 \pm 3{ }^{\circ} \mathrm{C}$. The simulated soil was prepared with $23 \%$ of loamy silt, $23 \%$ of organic matter (cow manure), $23 \%$ of sand, and $31 \%$ of distilled water (all wt/wt). Biodegradation was monitored for 80 days by measuring the mass variation. The buried specimens were recovered, washed with distilled water, and dried at ambient temperature until there was no further weight variation, and then weighed. After weighing, the specimens were buried again. The experiments were performed in quadruplicate.

\section{Results and Discussion}

The isolated cardanol was verified by GC-MS and its purity was confirmed ( $66.25 \%$ of monounsaturated, $29.04 \%$ di-unsaturated, and $4.71 \%$ saturated). Modifications in sponge gourd fibers after chemical treatment have been already discussed in earlier studies ${ }^{[28,29]}$.

In all chemical treatments of this study the same concentration of $\mathrm{NaClO}(1 \mathrm{wt} \%)$ was used, that is why in following discussions only the concentrations of $\mathrm{NaOH}$, which varied ( 5 and $10 \mathrm{wt} \%$ ), will be mentioned.

It is important to study the degree of crosslinking of thermoset materials, because it is linked directly to the properties of the final material. Figure 2 shows the results of crosslinking degree obtained by the gravimetric technique based on the swelling experiments to the thermoset plastic.

$0{ }^{\circ} \mathrm{C}$ represents the thermoset plastic which was cured at ambient temperature for $48 \mathrm{~h}$ and it did not undergo any post-cure process. After this period, the material presented a crosslinking degree of $88.53 \% \pm 0.34$. Besides being cured at ambient temperature for $48 \mathrm{~h}$, thermoset plastic samples were also post-cured for $2 \mathrm{~h}$ in temperature ranges of 60,80 , and $100^{\circ} \mathrm{C}$ in which crosslinking degree was of $93.54 \pm 0.84,93.57 \pm 0.36$, and $95.67 \% \pm 0.40$, respectively. Temperatures over $100{ }^{\circ} \mathrm{C}$ were tested as well, but they deformed the materials.

Subsequently, the temperature of post-cure was fixed at $100{ }^{\circ} \mathrm{C}$, which showed the highest crosslinking degree to the studied time interval, and the crosslinking degree was investigated to different time ranges, as shown in Figure 3 below.

The crosslinking degree to post-cure time ranges of 30 , $60,120,180,240,300$, and $360 \mathrm{~min}$ was $92.45 \pm 0.45,94.04$ $\pm 0.95,94.48 \pm 0.80,95.53 \pm 0.26,96.66 \pm 0.14,96.68 \pm 0.22$, and $96.88 \% \pm 1.03$, respectively. The crosslinking degree increased with increasing temperature and it did not show any significant variation from 240 minutes.

Considering the results of the experiments, the cure and post-cure conditions to the thermoset plastic were defined to be $48 \mathrm{~h}$ at ambient temperature in dispensing hood and $4 \mathrm{~h}$ at $100^{\circ} \mathrm{C}$ in oven, respectively. These conditions were also tested to biocomposites and the cure time of $48 \mathrm{~h}$ in dispensing hood was to guarantee total liberation of the used catalyst (DETA).
The results of the crosslinking degree experiments were verified by DSC. It is one of the most used techniques to study the cure of thermoset materials. Figure 4 shows the DSC curve obtained by monitoring the cure reaction of the thermoset plastic.

The cure reaction showed a large exothermic process at $87.76^{\circ} \mathrm{C}$ and total heat of $92.95 \mathrm{~J} / \mathrm{g}$. The endothermic event

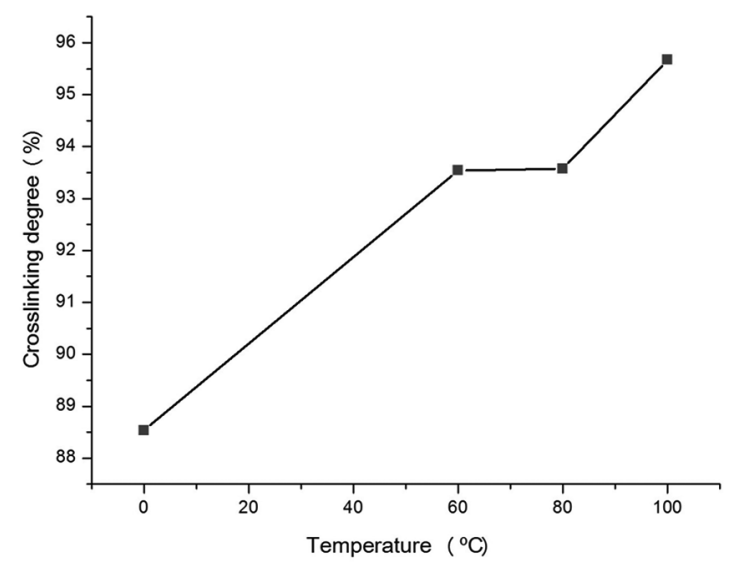

Figure 2. Crosslinking degree to different ranges of post-cure temperature.

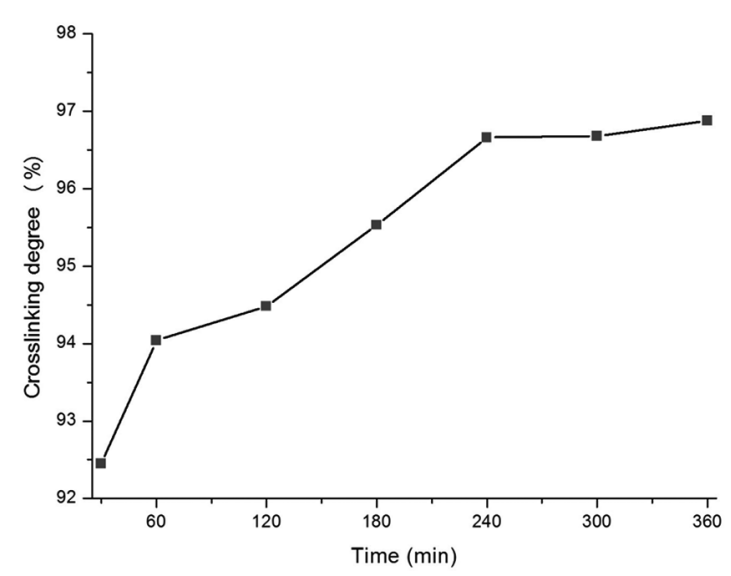

Figure 3. Crosslinking degree to different ranges of post-cure time.

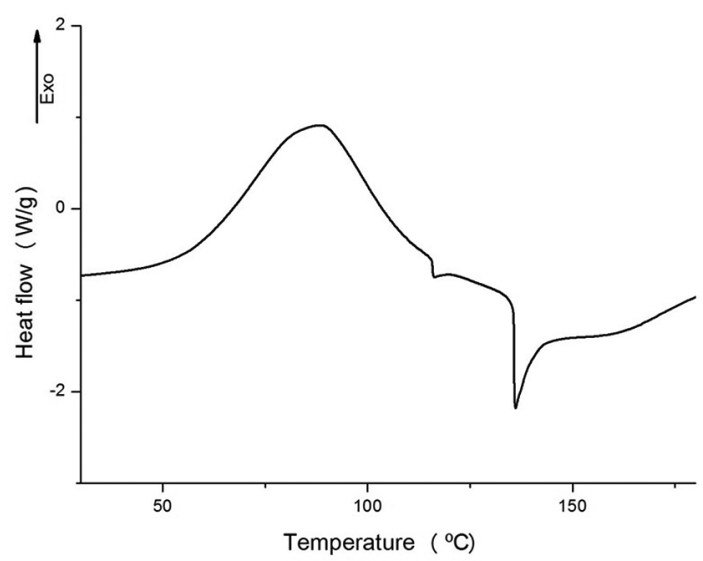

Figure 4. DSC curve to the cure reaction of thermoset plastic. 
at $136{ }^{\circ} \mathrm{C}$ is because of dehydration. After investigations on the thermoset plastic, from this point forward biocomposites will also be discussed. For convenience, thermoset plastic, biocomposite reinforced by untreated sponge gourd fibers, and those reinforced by sponge gourd fibers treated with $\mathrm{NaOH} 5$ and $10 \mathrm{wt} \%$ were labeled as TP, BFB, BF5, and $\mathrm{BF} 10$, respectively.

The conversion degree of the TP and biocomposites were studied by DSC, which curves are shown in Figure 5.

All materials presented a variation in baseline around $60{ }^{\circ} \mathrm{C}$. This variation was attributed to glass transition temperature ( $\mathrm{Tg}$ ), which was calculated by the method based on ASTM D3418 ${ }^{[30]}$. Maffezzoli et al. studied biocomposites with matrix based on cardanol and reinforced by natural fibers. They found a $\mathrm{Tg}$ of $56^{\circ} \mathrm{C}$ to their materials ${ }^{[31]}$.

There was not any exothermic event related to residual heat for the TP or any biocomposites. It indicated that cure conditions applied to the TP were also appropriate to the biocomposites, providing complete conversion, and consequently complete cure of all materials. These DSC results on materials cure validated those observed in the crosslinking degree experiments.

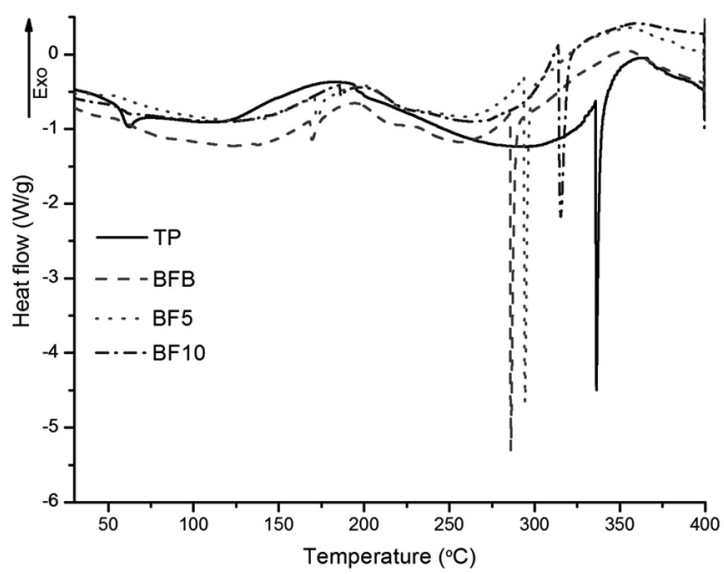

Figure 5. DSC curves to TP, BFB, BF5, and BF10.
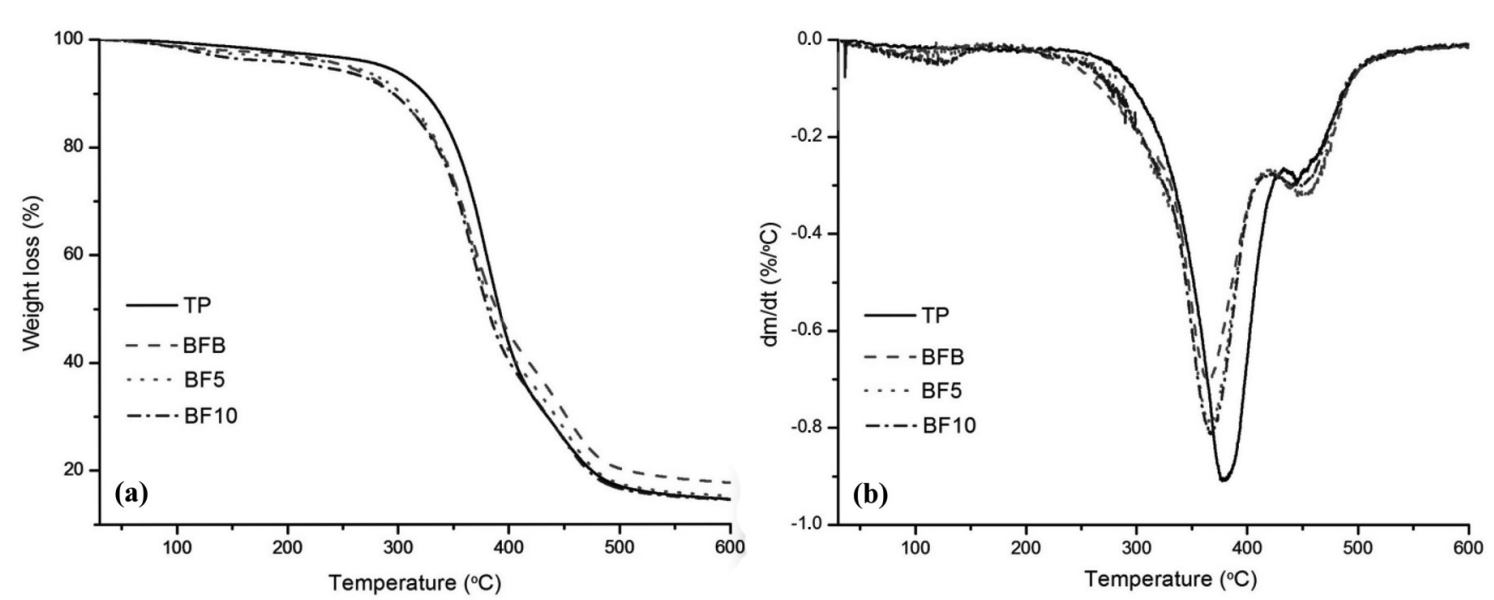

A short endothermic event was observed at 169, 172, and $187^{\circ} \mathrm{C}$ to $\mathrm{BFB}, \mathrm{BF} 5$, and $\mathrm{BF} 10$, respectively. It was assigned to dehydration and not observed to TP due to its hydrophobicity. The deep endothermic event at 336, 286, 294 , and $315^{\circ} \mathrm{C}$ refers to degradation of TP, BFB, BF5, and $\mathrm{BF} 10$, respectively. The TP is a little more thermally stable than biocomposites. However, chemical treatment increased the thermal stability of the biocomposites, especially BF10. It happened because the treatment partially removes lignin and hemicellulose, which start to degradate at low temperature ranges. Chemical treatment also removes surface waxes, promoting better adhesion between biocomposite phases. The better the interaction between fiber and matrix, the higher is the initial temperature of thermal degradation.

The weight variation of the materials as a function of temperature was studied by Thermogravimetry. TG and DTG (Differential Thermogravimetry) curves to the thermoset plastic and biocomposites are shown in Figure 6.

TG curves (Figure 6a) showed a small weight loss from room temperature to $160^{\circ} \mathrm{C}$ of $2.12,2.84$, and $3.84 \%$ to $\mathrm{BFB}$, $\mathrm{BF} 5$, and BF10, respectively. This process corresponds to loss of water and it was not observed to TP because of its hydrophobicity, as also seen in DSC curves. The water content in the biocomposites increased with increased concentration of $\mathrm{NaOH}$. It occurred because alkaline treatment exposed the hydroxyl groups of the fiber, which increased the interaction with water. Modibbo et al. reported alkaline treatment of fibers increases the moisture uptake ${ }^{[32]}$.

DTG curves (Figure 6b) showed two stages of weight loss. In the first one, TP, BFB, BF5, and BF10 maintained thermal stability and maximum temperature peak up to about 338 and 379,316 and 365,324 and 366,326 and $367^{\circ} \mathrm{C}$, respectively. This event is related to the decomposition of lignin, hemicellulose, and cellulose $\mathrm{e}^{[33-35]}$ and degradation of soft segments of the polymer matrix. The second stage is attributed to degradation of carbonaceous residues. At the end of these two stages, TP, BFB, BF5, and BF10 showed $14.77,18.17,15.48$, and $14.55 \%$ of residues, respectively. TG and DTG data agree with DSC results.

Biocomposites mechanical behavior depends on synergy between the reinforcing agent and the matrix. Table 1

Figure 6. (a) TG and (b) DTG curves to TP, BFB, BF5, and BF10. 
shows mechanical properties to the thermoset plastic and biocomposites.

All materials were examined to study the influence of the sponge gourd fibers acting as reinforcement as well as the effects of chemical treatment on mechanical properties of biocomposites. Remarkable changes were observed. There was an increase of $97.67,89.86$, and $144.38 \%$ in tensile strength of BFB, BF5, and BF10, respectively, when compared to TP. Young modulus and breaking load values to BFB, BF5, and BF10 showed an increase of 126.58 and $118.14,124.27$ and $102.93,138.15$ and $144.12 \%$, respectively, when compared to TP. All biocomposites presented superior mechanical properties compared to TP, especially BF10. As known, lignocellulosic fibers can be an efficient reinforcement as long as adequate is their interaction with the polymer matrix. These results indicated that sponge gourd fibers treated with $\mathrm{NaOH} 10 \mathrm{wt} \%$ had better interaction with polymer matrix, allowing a greater

Table 1. Mechanical properties to the TP and biocomposites.

\begin{tabular}{ccccc}
\hline & $\begin{array}{c}\text { Tensile } \\
\text { strength } \\
(\mathbf{M P a})\end{array}$ & $\begin{array}{c}\text { Young's } \\
\text { modulus } \\
\mathbf{( G P a )}\end{array}$ & $\begin{array}{c}\text { Breaking load } \\
\mathbf{( N )}\end{array}$ & $\begin{array}{c}\text { Deformation } \\
(\mathbf{\%})\end{array}$ \\
\hline TP & $7.30 \pm 0.55$ & $1.73 \pm 0.23$ & $232.74 \pm 38.82$ & 0.86 \\
$\mathrm{BFB}$ & $14.43 \pm 1.92$ & $3.92 \pm 0.25$ & $507.70 \pm 38.04$ & 0.77 \\
$\mathrm{BF} 5$ & $13.86 \pm 1.82$ & $3.88 \pm 0.41$ & $472.32 \pm 75.20$ & 0.75 \\
$\mathrm{BF} 10$ & $17.84 \pm 4.08$ & $4.12 \pm 0.28$ & $568.17 \pm 136.30$ & 1.05 \\
\hline
\end{tabular}

stiffness, better distribution of tension and therefore, better Tensile testing results. DSC and TG data corroborated these results.

After Tensile testing, micrographs were recorded from fractured surface of specimens to investigate morphology and interaction between polymer matrix and sponge gourd fibers. Figure 7 shows the micrographs to the TP and biocomposites.

Micrographs showed voids on the fractured surface of TP (Figure 7a), probably because of cure reaction, which is exothermic, air incorporation or water presence. The surface of BFB (Figure 7b) and BF5 (Figure 7c) showed adhesive fracture, characterized by interface debonding between fiber and matrix due to low interaction and poor adhesion. On the other hand, BF10 surface (Figure 7d) did not present any voids or debonding, suggesting good compatibility between sponge gourd fibers and polymer matrix, which led to a better distribution of tension.

Figure 8 shows the fractured region and lays emphasis on debonding in BFB as well as better adhesion and flatter fracture in BF10 at macroscopic level.

It is known that pretreatment can enable better adhesion between matrix and fiber ${ }^{[36,37]}$. Micrographs and the photograph showed that the alkaline treatment provided better interface between sponge gourd fibers and cardanol-based resin, especially that one with $\mathrm{NaOH} 10 \mathrm{wt} \%$. These results agree with those obtained to DSC, TG, and Tensile testing.
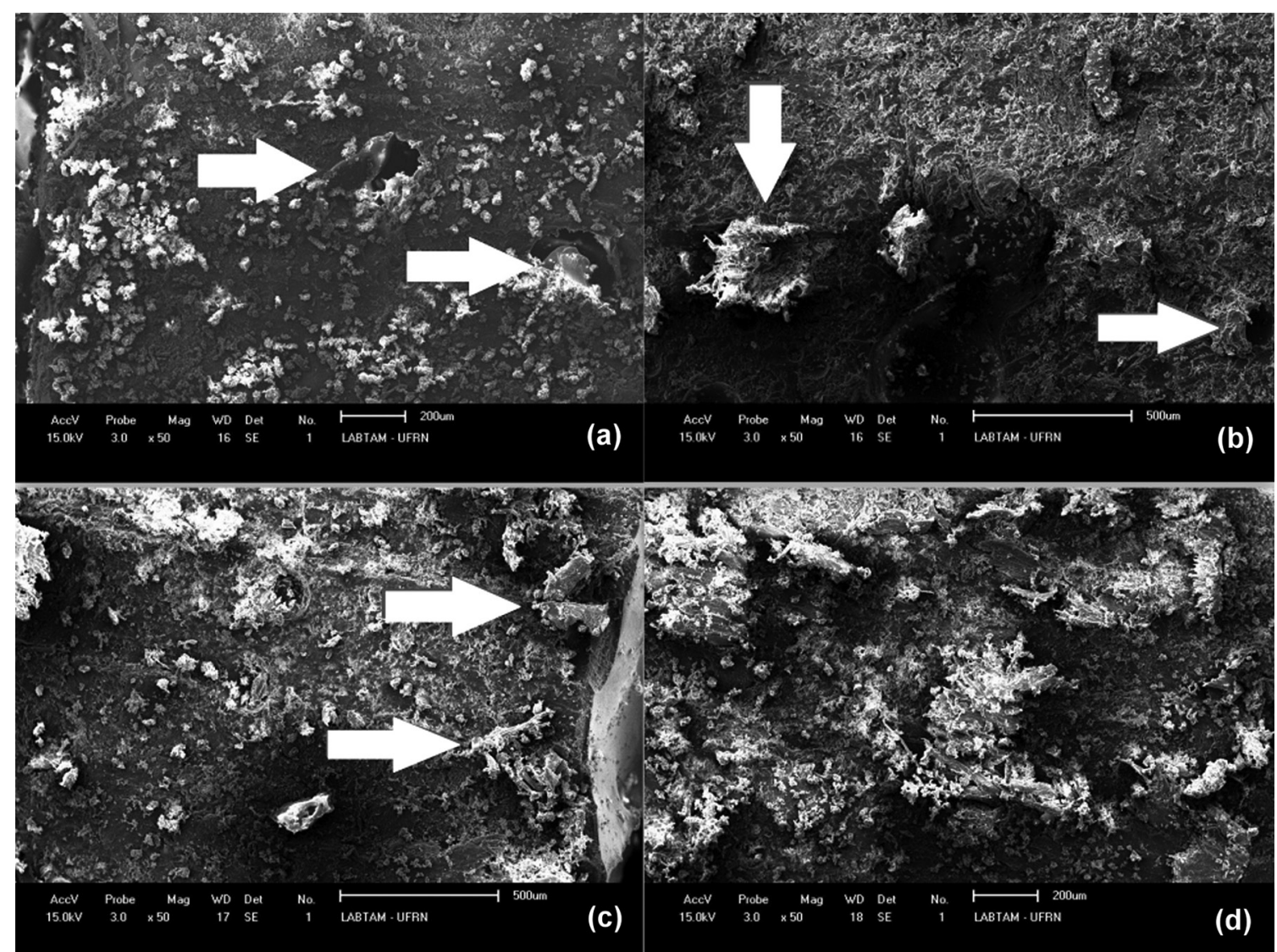

Figure 7. Micrographs of fractured surface to (a) TP (50×, $200 \mu \mathrm{m})$; (b) BFB (50×, $500 \mu \mathrm{m})$; (c) BF5 (50×, $500 \mu \mathrm{m})$ and (d) BF10 $(50 \times, 200 \mu \mathrm{m})$. 


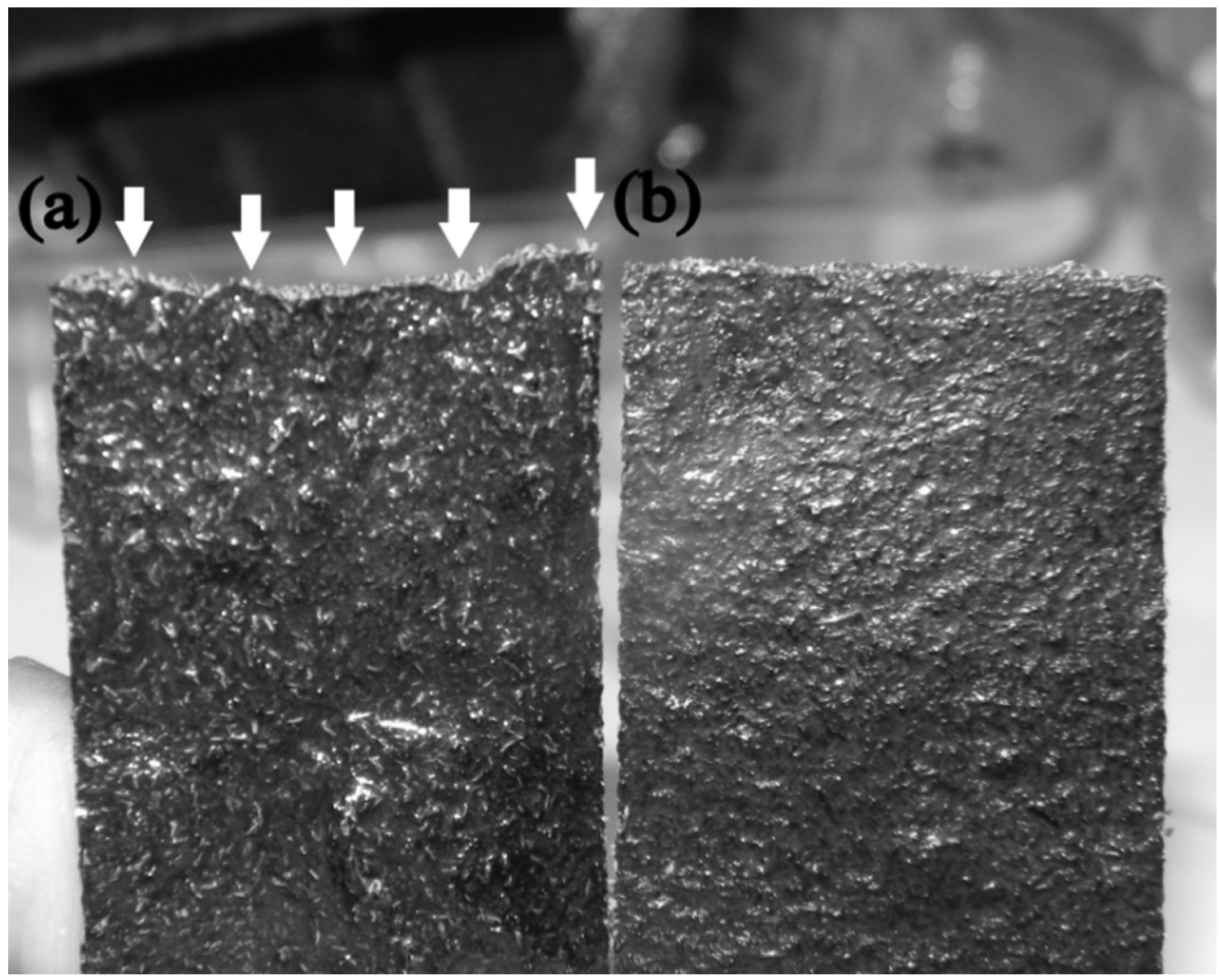

Figure 8. Fractured region after Tensile testing to (a) BFB and (b) BF10.

There is a growing search for more durable materials during use and less damage to environment when disposed. The results of the behavior of the TP and biocomposites in simulated soil after 80 days are in Figure 9.

The weight increase in TP, BFB, and BF5 in the first days occurred due to absorption or adsorption of water by these materials, which were more resistant to hydrolysis ${ }^{[38]}$ when compared to BF10. TP showed the greatest water incorporation because of the voids in this material, as seen by SEM. The weight increase of the materials can also be attributed to growth of microorganisms involved in polymer degradation.

During the investigated period of time ( 80 days), a weight loss of $10 \pm 36.52,41 \pm 49.15,65 \pm 24.39$ and $66 \%$ $\pm 13.28 \%$ to TP, BFB, BF5, and BF10, respectively, was observed. Polymers are degraded in biological systems by oxidation and hydrolysis. The first stage of aging in simulated soil corresponds to the abiotic phase, in which macromolecules hydrolyze and smaller molecules such as monomers and oligomers are formed ${ }^{[39]}$.

According to Sun and Tomkinson ${ }^{[40]}$, lignin protects the fiber from microorganisms action. Given this, it is possible to say that alkaline treatment was the responsible for the greatest weight decreases in BF5 and BF10 due to the removal of lignin content, which made the treated

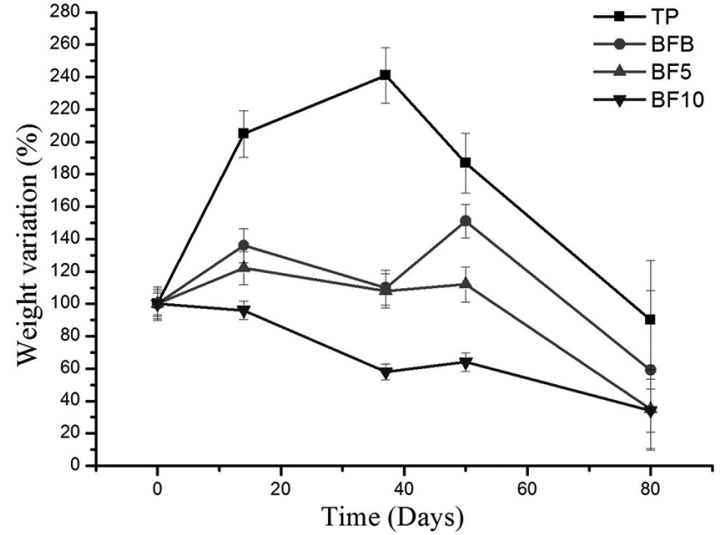

Figure 9. Biodegradation of TP and biocomposites.

fibers and their respective biocomposites more susceptible to biodegradation.

\section{Conclusions}

The effective use of cardanol as a building block for the development of a thermosetting matrix reinforced by sponge gourd fibers was investigated. A combination of cure 
at ambient temperature and post-cure were conducted to a higher handling time and better polymer matrix wettability as well as maximum crosslinking degree and complete cure. Although it does not replace classical instrumental techniques, the gravimetric method used to determine the crosslinking degree to the thermoset plastic showed that DETA can provide a satisfactory cure degree at room temperature and It was found to be an interesting alternative, and an indexing of tool for this polymer system, especially due to its low cost and easy performance. While that method supplied information on crosslinking degree, DSC results confirmed total conversion of groups involved in crosslinking and endorsed that cure and post-cure conditions applied to the thermoset plastic were appropriate to the biocomposites as well. DSC curves showed a Tg around $60{ }^{\circ} \mathrm{C}$ to the thermoset plastic and biocomposites, which means sponge gourd fibers did not affect the Tg. Although the thermoset plastic has had a little higher thermal stability than biocomposites, sponge gourd fibers seemed to be a viable reinforcement, especially due to extraordinary improvement in mechanical properties of the biocomposites. DSC and TG results showed that among biocomposites, that one reinforced by sponge gourd fibers treated with $\mathrm{NaOH} 10 \mathrm{wt} \%$ (BF10) had the highest thermal stability. BF10 also presented the best performance in Tensile testing and good incorporation, dispersion, and adhesion with polymer matrix, observed by SEM. After 80 days of simulated soil experiments was found that the presence of treated fiber allowed better biodegradability behavior to biocomposites.

This paper provided useful information and introduced the experimental set of results on the synthesis and characterization of a thermoset plastic and biocomposites prepared from a combination between a cardanol-based resin and sponge gourd fibers by a low-cost processing, which showed a good potential to several applications, from manufacturing of articles to furniture and automotive industries.

\section{References}

1. John, M. J., \& Thomas, S. (2008). Biofibres and biocomposites. Carbohydrate Polymers, 71(3), 343-364. http://dx.doi. org/10.1016/j.carbpol.2007.05.040.

2. Harvey, M. T., \& Caplan, C. (1940). Cashew nut shell liquid. Industrial \& Engineering Chemistry, 3(10), 1306-1310. http:// dx.doi.org/10.1021/ie50370a008.

3. Manjula, S., Sudha, J. D., Bera, S. C., \& Pillai, C. K. S. (1985). Polymeric resin from renewable resources: studies on polymerization of the phenolic component of coconut shell tar. Journal of Applied Polymer Science, 30(4), 1767-1771. http://dx.doi.org/10.1002/app.1985.070300440.

4. Tyman, H. P., Wilczynski, D., \& Kashani, M. A. (1978). Compositional studies on technical cashew nutshell liquid (CNSL) by chromatography and mass spectroscopy. Journal of the American Oil Chemists 'Society, 55(9), 663-668. http:// dx.doi.org/10.1007/BF02682455.

5. Mohapatra, S., \& Nando, G. B. (2014). Cardanol: a green substitute for aromatic oil as a plasticizer in natural rubber. Royal Society of Chemistry Advances, 4, 15406-15418. http:// dx.doi.org/10.1039/c3ra46061d.

6. Balachandran, V. S., Jadhav, S. R., Vemula, P. K., \& John, G. (2013). Recent advances in cardanol chemistry in a nutshell: from a nut to nanomaterials. Chemical Society Reviews,
42(2), 427-438. http://dx.doi.org/10.1039/C2CS35344J. PMid:23114456.

7. Corrales, F., Vilaseca, F., Llop, M., Gironès, J., Méndez, J. A., \& Mutjè, P. (2007). Chemical modification of jute fibers for production of green-composites. Journal of Hazardous Materials, 144(3), 730-735. http://dx.doi.org/10.1016/j. jhazmat.2007.01.103. PMid:17320283.

8. Zou, L., Jin, H., Lu, W., \& Li, X. (2009). Nanoscale structural and mechanical characterization of the cell wall of bamboo fibers. Materials Science and Engineering C, 29(4), 1375-1379. http://dx.doi.org/10.1016/j.msec.2008.11.007.

9. Rao, K. M. M., \& Rao, K. M. (2007). Extraction and tensile properties of natural fibers: vakka, date and bamboo. Composite Structures, 77(3), 288-295. http://dx.doi.org/10.1016/j. compstruct.2005.07.023.

10. Kumar, V., Kushwaha, P. K., \& Kumar, R. (2011). Impedancespectroscopy analysis of oriented and mercerized bamboo fiber-reinforced epoxy composite. Journal of Materials Science, 46(10), 3445-3451. http://dx.doi.org/10.1007/s10853-0115249-6.

11. Sen, T., \& Reddy, H. N. J. (2011). Applications of sisal, bamboo, coir and jute and natural composites in structural up gradation. International Journal of Inovation Management and Technology, 2(3), 186-191. http://dx.doi.org/10.7763/IJIMT.2011.V2.129.

12. Chandramohan, D., \& Marimuthu, K. (2011). A review on natural fibers. International Journal of Research and Reviews in Applied Sciences, 8(2), 194-206. Retrieved 20 January 2015, from http://www.arpapress.com/Volumes/Vol8Issue2/ IJRRAS_8_2_09.pdf

13. Dahlke, B., Larbig, H., Scherzer, H. D., \& Poltrock, R. J. (1998). Natural fiber reinforced foams based on renewable resources for automotive interior applications. Journal of Cellular Plastics, 34(4), 361-379. http://dx.doi.org/10.1177/0021955X9803400406.

14. Colom, X., Carrasco, F., Pages, P., \& Canavate, J. (2003). Effects of different treatments on the interface of HDPE/lignocellulosic fiber composites. Composites Science and Technology, 63(2), 161-169. http://dx.doi.org/10.1016/S0266-3538(02)00248-8.

15. Esmeraldo, M. A., Barreto, A. C. H., Freitas, J. E., Fechine, P. B. A., Sombra, A. B. S., Corradini, E., Mele, G., Maffezzoli, A., \& Mazzetto, S. E. (2010). Dwarf-green coconut fibers: a versatile natural renewable raw bioresource. Treatment, morphology, and physicochemical properties. BioResources, 5(4), 2478-2501. Retrieved 20 January 2015, from http://ojs.cnr. ncsu.edu/index.php/BioRes/article/view/BioRes_05_4_2478_ Esmeraldo_GFFSCMMM_Draft_Green_Coconut_Fibers

16. Barreto, A. C. H., Esmeraldo, M. A., Rosa, D. S., Fechine, P. B. A., \& Mazzetto, S. E. (2010). Cardanol biocomposites reinforced with juta fiber: microstructure, biodegradability, and mechanical properties. Polymer Composites, 31(11), 1928-1937. http://dx.doi.org/10.1002/pc.20990.

17. Barreto, A. C. H., Rosa, D. S., Fechine, P. B. A., \& Mazzetto, S. E. (2011). Properties of sisal fibers treated by alkali solution and their application into cardanol-based biocomposites. Composites Part A: Applied Science and Manufacturing, 42(5), 492-500. http://dx.doi.org/10.1016/j.compositesa.2011.01.008.

18. Barreto, A. C. H., Costa, A. E., Jr., Freitas, J. E. B., Rosa, D. S., Barcellos, W. M., Freire, F. N. A., Fechine, P. B. A., \& Mazzetto, S. E. (2013). Biocomposites from dwarf-green Brazilian coconut impregnated with cashew nut shell liquid resin. Journal of Composite Materials, 47(4), 459-466. http:// dx.doi.org/10.1177/0021998312441041.

19. Mazali, I., \& Alves, O. L. (2005). Morphosynthesis: high fidelity inorganic replica of the fibrous network of loofa sponge (Luffa cylindrica). Academia Brasileira de Ciências, 77(1), 25-31.

20. Satyanarayana, K. G., Guimarães, J. L., \& Wypych, F. (2007). Studies on lignocellulosic fibers of Brazil. Part I: Source, 
production, morphology, properties and applications. Composites. Part A, Applied Science and Manufacturing, 38(7), 1694-1709. http://dx.doi.org/10.1016/j.compositesa.2007.02.006.

21. Tanobe, V. O. A., Sydenstricker, T. H. D., Munaro, M., \& Amico, S. C. (2007). A comprehensive characterization of chemically treated sponge-gourds (Luffa cylindrical). Polymer Testing, 24(4), 474-482. http://dx.doi.org/10.1016/j. polymertesting.2004.12.004

22. Habibi, Y., El-Zawawy, W. K., Ibrahim, M. M., \& Dufresne, A. (2008). Processing and characterization of reinforced polyethylene composites made with lignocellulosic fibers from Egyptian agro-industrial residues. Composites Science and Technology, 68(7-8), 1877-1885. http://dx.doi.org/10.1016/j. compscitech.2008.01.008.

23. Le Troedec, M. L., Sedan, D., Peyratout, C., Bonnet, J. P., Smith, A., Guinebretiere, R., Gloaguen, V., \& Krausz, P. (2008). Influence of various chemical treatments on the composition and structure of hemp fiber. Composites Part A: Applied Science and Manufacturing, 39(3), 514-522. http:// dx.doi.org/10.1016/j.compositesa.2007.12.001.

24. Kumar, P. P., Paramashivappa, P. J., Vithayathil, P. J., Subra Rao, P. V., \& Srinivasa, R. A. (2002). Process for isolation of cardanol from technical cashew (Anacardium occidentale.) nut shell liquid. Journal of Agricultural and Food Chemistry, 50(16), 4705-4708. http://dx.doi.org/10.1021/jf020224w. PMid: 12137500.

25. American Society for Testing and Materials - ASTM. (2006). ASTM D2765-11: standard test methods for determination of gel content and swell ratio of crosslinked ethylene plastics. West Conshohocken: ASTM International.

26. American Society for Testing and Materials-ASTM. (2014). ASTM D638-14: standard test method for tensile properties of plastics. West Conshohocken: ASTM International.

27. American Society for Testing and Materials -ASTM. (2014). ASTM D3039/D3039M-14: standard test method for tensile properties of polymer matrix composite materials. West Conshohocken: ASTM International.

28. Silva, A. L., Costa, A. E., Jr., Nascimento, D. M., Rosa, M. F., Fechine, P. B. A., \& Mazzetto, S. E. (2013). Efeito do tratamento alcalino e branqueamento na morfologia e no índice de cristalinidade da fibra de bucha vegetal (Luffa cylindrical). In Anais do $53^{\circ}$ Congresso Brasileiro de Química (pp. 2). Rio de Janeiro: Associação Brasileira de Química. Retrieved 17 September 2014, from http://www.abq.org.br/cbq/2013/ trabalhos/12/2405-16576.html

29. Silva, A. L., Costa, A. E., Jr., Nascimento, D. M., Silva, M. A. S., Sombra, A. S. B., Rosa, M. F., Fechine, P. B. A., \& Mazzetto, S. E. (2013). Modificações espectroscópicas vibracionais e nas propriedades dielétricas em fibras de bucha vegetal (Luffa cylindrica) após tratamento químico. In Anais do $53^{\circ}$ Congresso Brasileiro de Química (pp. 3). Rio de Janeiro: Associação Brasileira de Química. Retrieved 17 September 2014, from http://www.abq.org.br/cbq/2013/trabalhos/12/2408-16576. html

30. American Society for Testing and Materials-ASTM. (2015). ASTM D3418-15: standard test method for transition temperatures and enthalpies of fusion and crystallization of polymers by differential scanning calorimetry, West Conshohocken: ASTM International.

31. Maffezzoli, A., Calò, E., Zurlo, S., Mele, G., Tarzia, A., \& Stifani, C. (2004). Cardanol Based Matrix Biocomposites Reinforced With Natural Fibers. Composites Science and Technology, 64(6), 839-845. http://dx.doi.org/10.1016/j. compscitech.2003.09.010.

32. Modibbo, U. U., Alyiu, B. A., Nkafamiya, I. I., \& Manji, A. J. (2007). The effect of moisture imbibition on cellulosic bast fibres as industrial raw materials. Internacional Journal of Physical Science, 2(7), 163-168. Retrieved 20 October 2014, from http://www.academicjournals.org/journal/IJPS/articleabstract/69B629713202

33. Khan, A. F., \& Ahmad, S. R. (1996). Chemical Modification and spectroscopic analysis of Jute fibre. Polymer Degradation \& Stability, 52(3), 335-340. http://dx.doi.org/10.1016/01413910(95)00240-5.

34. Antich, P., Vázquez, A., Mondragon, I., \& Bernal, C. (2006). Mechanical behavior of high impact polystyrene reinforced with short sisal fibers. Composites Part A: Applied Science and Manufacturing, 37(1), 139-150. http://dx.doi.org/10.1016/j. compositesa.2004.12.002.

35. Szczesniak, L., Rachocki, A., \& Tritt-Goc, J. (2008). Glass transition temperature and thermal decomposition of cellulose powder. Cellulose (London, England), 15(3), 445-451. http:// dx.doi.org/10.1007/s10570-007-9192-2.

36. Vázquez, G., González, S., Freire, S., \& Antorrena, G. (1997). Effect of chemical modification of lignin on the gluebond performance of lignin-phenolic resin. Bioresource Technology, 60(3), 191-198. http://dx.doi.org/10.1016/S0960-8524(97)000308.

37. Kharade, A. Y., \& Kale, D. D. (1998). Effect of lignin on phenolic novolak resins and moulding powder. European Polymer Journal, 34(2), 201-205. http://dx.doi.org/10.1016/ S0014-3057(97)00118-3.

38. Rosa, D. S., Bardi, M. A. G., Guedes, C. G. F., \& Angelis, D. A. (2009). Role of polyethylene-graft-glycidyl methacrylate compatibilizer on the biodegradation of poly ( $\varepsilon$-caprolactone)/ cellulose acetate blends. Polymers for Advanced Technologies, 20(12), 863-870. http://dx.doi.org/10.1002/pat.1302.

39. Kyrikou, J., \& Briassoulis, D. (2007). Biodegradation of agricultural plastic films: a critical review. Journal of Polymers and the Environment, 15(12), 125-150. http://dx.doi.org/10.1007/ s10924-007-0053-8.

40. Sun, R. C., \& Tomkinson, J. (2002). Comparative study of lignins isolated by alkali and ultrasound-assisted alkali extractions from wheat straw. Ultrasonics Sonochemistry, 9(2), 85-93. http://dx.doi.org/10.1016/S1350-4177(01)00106-7. PMid:11794023. 